\title{
Separation Process of Britain From the EU and its Impacts on Both Sides
}

\author{
Huseyin Ozdeser ${ }^{1}$
}

\begin{abstract}
:
EU has a significant role in the world politics and economics. The importance of Brexit is unquestionable for the world countries whether they are parts of the EU or not.

Developments and events taken place in the EU affect politically and economically member states as well as other countries of the world.

The Britain' exit from the EU is not expected to affect Britain and the EU only but all the countries which have economical and political relations with the EU. Britain's process of separation from the EU will have negative impacts on the EU's citizens who live in Britain, and the British citizens who live in the EU.
\end{abstract}

The study aims to analyze the impacts of Brexit process for both sides.

Keywords: Britain, European Union, Brexit, separation.

JEL Classification: Z19.

\footnotetext{
${ }^{1}$ Near East University, e-mail:huseyin.ozdeser@neu.edu.tr
} 


\section{Introduction}

The important question to be answered is how the UK economy will be affected as a result of the decision taken in the 2016 referendum to leave the EU. Fall in investments or slide in stock market gives a sign that there will be important short term effects. However, it is more important to analyze how the economy will be affected in the long-term after the deterioration of relations with Brussels.

The UK leaving the European Union is not only a difficult and risky situation for the country, but it is also a situation fraught with complexities and risks for the European Union. The referendum held in the UK determines whether the country would stay or leave the EU presents a new direction for the country which involves many risks and requires significant courage. It is inevitable that, the referendum held for the EU has an impact on the other members of the European Union.

For example, the EU members who are willing to leave the EU but cannot attempt to have one could be encouraged by the Brexit result to hold a referendum or at the very least, they may begin to consider such a course of action. Consequently the impact of Brexit may create a domino effect in the EU, which could increase the risk of dissolution of the EU as a whole. It is commonly observed in all developing institutions that various risks and unexpected problems can arise.

The EU should have closer attention to the complaints made by the UK and should have achieved closer coordination to find solutions to the difficulties. It is possible that EU has not applied such a strategy previously because it was unthinkable that, such a scenario as Brexit could actually materialize. After this process, the EU must focus on managing the problems of the members and Brexit in a certain way. Also this must be an important stimulant factor for the EU.

The EU is enlarging, no limits have been placed on the number of countries that can be accepted as members. Hence it is unknown where the borders of the EU will end. This means that the number of members will continue to rise, but each increase will also bring new problems that must be confronted. Resultantly, the EU must be cautious about the steps that implements in coordinating its relations with its members.

IMF has lowered its forecasts for global economic growth due to the unexpected vote made by the people of the UK to leave the EU, as this has created a wave of uncertainty. According to IMF, Brexit vote increased the uncertainty in economics and politics as well as the institutional uncertainty. Overall this will create negative impacts for European macroeconomics. The economies in the UK and Europe will be negatively affected as the referendum has caused a change of government in Britain. Global growth will decelerate which will lead to the implementation of structural reforms with the aim of strengthening the banking system. 


\section{European Union and Britain}

The European Union is a kind of a union with the goal of securing peace and increasing welfare (Baimbridge and Burkitt, 2000). According to Amsterdam Treaty a common market would be established, and common policies would be applied for achieving a harmonized, balanced and sustainable development of economic activities. Furthermore, there should be high levels of employment and social protection with equality between men and women. There would be sustainable and non-inflationary economic growth along with a high degree of competitiveness and an increase in the quality of the environment. This would consequently raise the quality and standard of living of the people (Amsterdam Treaty, Article 2, Part One, Principles, El Agraa, 2007). At the end of the Second World War Europe was divided and people were uncertain about the future (Zestos, 2006). After this time, cooperation between nations, instead of competition, became more important and more meaningful. As a result of rising international cooperation, after the Second World War, the United Nations were established. Through the establishment of the United Nations, some regional integration also started whereby, the countries, goods and services and also people started to experience greater freedom of movement.

Furthermore the countries started to have integrated markets and at the same time followed common policies. The European Union is an example of this process. Integration attempts were also observed in North America, Latin America, the Caribbean, South and South East Asia and also parts of Africa. The European Union can be seen as a model caused the breakdown of states. In recent times, the power of states has fallen for various reasons, such as countries around the world have become increasingly integrated, creating a more complex world, people are more mobile, states are not always capable of meeting all security requirements, countries are not able to meet all their citizens' demands for goods and services, and also the speed of improvements in technology, science and communication (McCormick, 2005). Due to the process of market integration in Europe industries are becoming more concentrated and as a result, the member states and regions are becoming increasingly specialized (The EU economy: 2000 review).

It is hard to estimate what the total number of member nations of the European Union will be in the future. As with all other organizations, when the EU enlarges the problems that it will face will also increase. The latest and most significant problem that the EU is facing is the referendum held in the United Kingdom. Furthermore, at this time, there are also some member countries in the EU that are experiencing economic problems, such as Greece, Porugal, Spain and Ireland.

The EU has also welcomed previously socialist countries as members such as Bulgaria and Romania that they are now operating under liberal economic systems. In other words the EU has increased the number of countries in the world that are functioning under liberal economic systems. The number of countries that have applied openness has increased and because of this factor the volume of global trade 
has increased as the number of countries exporting and importing has increased as a result of the rise in the number of EU member countries. The welfare of the previous socialist EU member countries is now significantly improved. The EU has had an important effect on the economic agendas of member countries. In the 1990s, many of Western European countries' economies were influenced by the Maastricht Criteria (Dyker, 1999). The establishment of a common market is related to which of three policies are particularly important, agriculture, competition, and trade (Pelkmans, 2001).

Integration means the relaxation of restrictions enabling the movement of goods and services between countries and the application of common policies (Nello, 2005). Globalization causes an increase in the integration of economies around the world by trade and finance and by the improvements in telecommunications and transportation. People around the world are demanding similar products and this is causing the globalization spread around the world. Consumers will always demand the products that are made with higher quality at cheaper prices, regardless of where they are produced. Furthermore, they all prefer to invest in locations that are deemed to be profitable. They have followed this course of action to maintain competitiveness (Salvatore, 2007). Although countries share the same world they differ in terms of cultural, economic and social aspects. All the countries have relations with each other. These relations can be economic, political, military, sporting, and others. However economic relations between countries are the most important. For example, political relations might be affected based on economics (Seyidoğlu, 2007). One of the most important characteristics of globalization is the fact that encourages competition, which is particularly important for improving the efficiency of the economy.

As a result of the regional economic integration the distribution of the sources between the sectors is rearranged due to the need for adapting the increasing competition (Karluk, 1996). International interdependence is not restricted to the trade of goods and services. Interdependence in financial markets can include government lending or borrowing more than in the goods and services markets (Yarbrough, 2006).

International trade benefits the people in different countries. For example exporting from China, United States or from Europe can create job opportunities for many people in those areas (Feenstra and Taylor, 2012). It is not possible to say that international trade occurs because of the productivity differences of the individuals in different activities. The differences in the preferences of the people can cause international trade to take place (Eicher et al., 2009).

\section{Globalization}

After the Second World War there were different forms of economic integration where later discontinued (El Agraa, 2004). Globalization is a process where the 
countries are becoming more interdependent in terms of their economies, governments and environments, and the interconnectedness of people and societies. The Swiss Economic Institute (KOF) has measured the degree of globalization by combining economic, political and social measures (Daniels et al., 2011).

Table 1. The Top Ten Most Globalized and Ten Least Globalized Countries

Degree Country Degree Country

\begin{tabular}{llll}
1 & Belgium & 172 & Sao Tomeand Principe \\
2 & Austria & 173 & Tonga \\
3 & Holland & 174 & Comoros \\
4 & Switzerland & 175 & Bhutan \\
5 & Sweden & 176 & Eritrea \\
6 & Denmark & 177 & Lao,PDR \\
7 & Canada & 178 & Equatorial Guinea \\
8 & Portugal & 179 & Solomon Islands \\
9 & Finland & 180 & Kiribati \\
10 & Hungary & 181 & Mynamar \\
\hline
\end{tabular}

Multinational companies predominantly exist for two reasons. The first reason is that they want to lower labor costs and the second for environmental reasons. In some countries the rules concerning the protection of the environment are not so restrictive and this attracts many companies to move to these countries. For these two reasons in particular vast majority of multinational companies prefer to have investments in China improving their levels of profitability and competitiveness. The needs and wants of the consumers are unlimited and because of this reason, consumers will always demand products that are not produced in their domestic country resultantly, globalization processes a dynamic process. Globalization causes the world to transform into a large village. In particular the developments in the telecommunication sector has enabled people around the world to constantly maintain effective communications with each other. Globalization is evident in all sectors and globalization in insurance company operations is continuously rising (Kidvell and Blackwell, 2006). Furthermore, as a result the increase in the volume of international trade, the demand for international financial services is growing (Cecchetti, 2008). Without globalization in the banking sector it would not be possible for international trade to operate in an effective manner. Provided that the volume of international trade rises, then this will increase the level of globalization in the financial sector, particularly in banking.

The European Union is a large global trading block where the goods, services and factors of production are mobile (Thalassinos and Pociovalisteanu, 2009). It is an integration process of 27 member countries. Furthermore, the European Union is a vast peace project because as long as the member countries exist in the same block under the umbrella of the EU, the likelihood of conflicts such as the Second World War will be vastly reduced (Özdeşer, 2015). 
The integration process for the members of the EU is not only because of foreign policy. All the member countries have their own foreign policy interests. Thus, it is extreme challenging to satisfy all the demands of the 27 member countries. Furthermore, similar problems can be seen in the case of the application of the common monetary policy. The economies of all euro zone countries cannot be expected to function under the same structure, and therefore it is difficult for the member countries to apply the same monetary policies (Thalassinos et al., 2015).

Globalization caused the people between the countries to create closer relations with each other. Specially the improvement in the communication and international trade also improved the globalization in culture and social life. Based on globalization a lot of similarities can be seen about the products that the consumers consume. In a way the globalization causes the cultural and social life diversity to be reduced. It can be said as a result of globalization process the world is moving through the single standard. The multinational companies have an important additive to the speed of globalization. On the other hand, the improvements in the transportation gave a big chance for the consumers to visit foreign countries much easier and more frequently than before. By this way the consumers could find a chance to recognize the different cultures more closely. Globalization has created an integrative impact for the people of the world.

\section{The Impacts of Brexit on Global Economic Growth}

The policy makers in Europe and in the United Kingdom must be cautious with the policies they will apply to clear the uncertainty of Brexit in order to minimize the negative effects of Brexit on economic growth. According to the IMF the growth rate in the global economy is expected to be 3.4 percent in 2017, which is a $0.1 \%$ reduction on the pre-Brexit forecast. For the euro area, the growth rate is estimated to be $1.4 \%$ a reduction of $0.2 \%$. The impacts of Brexit will gradually be observed in the long run. The effects will continue through additional economic and political uncertainty in the long run. More ever, the future impact of Brexit is uncertain.

Uncertainty in economics asserts a negative impact on consumer confidence and also on the confidence of investors. One of the most important factors for investors and consumers is trust. Therefore, it is necessary to build a reliable economic atmosphere for economic actors by increasing the certainty. Brexit has created such a level of uncertainty for many economic institutions in the UK and in the EU, that the negative economic developments in these areas will cause negative impacts on the global economic growth rate.

\section{United Kingdom After Brexit}

The United Kingdom constitutes of four countries. For this reason, politics within the United Kingdom is diverse (Hancock, 2007). Furthermore, this explains the political diversity during the Brexit process. In England and Walls, most of the people voted to 
leave the EU, while in Scotland and Northern Ireland the majority of the people voted to remain in the EU. During the Brexit campaign the political leaders in Scotland and Northern Ireland followed a different direction from those in England. The question remains whether the political leaders in Scotland and Northern Ireland will continue to maintain separate policies from England after Brexit or whether this separation will be absorbed after the short term.

After Brexit, it is certain that there is a risk of collapse for the UK economy as it was already known that a referendum will be held in Scotland about whether to remain as part of the UK. The possibility of a referendum taking place in Scotland or in Northern Ireland after Brexit has increased due to the encouraging factor of the vote to leave the EU.

\section{The Impacts of Brexit in UK Trade}

The EU is the UK's largest trade partner. Therefore, the UK's membership in the EU has lowered the cost of trade between the two blocks. As a consequence of this factor, prices become lower as businesses find greater opportunities to increase exports. Undoubtedly, leaving the EU will cause a fall in trade between the UK and the EU, because there will be higher tariffs or other trade barriers. As the UK will no longer be an EU member the UK will not have the opportunity to benefit from future EU trade potential. Another important question is whether it will be possible for the UK to achieve improved trade relations with countries outside the EU. It is also important to mention at this point that the changing structure of the relations between the UK and the EU after Brexit is uncertain which will inevitably create uncertainty about the costs of trade between the two parties.

The situation for the UK can be linked to the situation of a fish coming out of the water. The UK needs a long time period to recover the shocks of Brexit. Because Brexit is not something that the UK was prepared so well for the impacts that it will face when majority would vote against. After this process, everything is very critical for the UK. Now the government, the labor unions, private and public sectors and non-governmental institutions should act in coordination for shaping the structure of the political and economic relations with the EU. If UK cannot take the steps that it should take then in the future the negative impacts of Brexit can be felt much worse. Undoubtedly, the EU will not want the UK to be far away from the EU as it is an important alliance.

\section{Conclusion and Recommendation}

Undoubtedly, UK leaving the EU is a historical event which was not anticipated by many people around the world and it appears that its impacts on the UK, the EU and also the world will continue in the long run. 
Brexit currently is one of the most important topics in the history of EU. The United Kingdom is one of the countries in the world that plays a significantly important role in global politics and economics. Brexit did not only affect the politics and economics in the United Kingdom but also on a global basis. After Brexit, some negative effects have been observed in the economics of the United Kingdom and the European Union. Brexit will cause a decline in the attempts made by European Union to achieve higher integration. However, Brexit does not mean that other EU members states will leave the Union. The politicians who are active in the EU member countries may have to apply defensive policies. In the EU there are two competing ideologies for the future of Europe. According to the Presidency of the European Commission there will be further integration and the crises in the European Union should be solved by European solutions within the member states which means additional power for the EU institutions and also it points out that many problems in Europe need more Europe. On the other hand, according to the European Council if there is more centralization within the EU then the citizens of the member states may be protected.

The difference in the regional votes in the referendum has created some risks for the United Kingdom which includes its potential collapse. As previously stated Scotland held a referendum on whether to stay or leave the United Kingdom and the majority voted to remain. During the Brexit process different policies adopted by the political leaders in Scotland and Northern Ireland compared to England has increased the concerns of the collapse of the United Kingdom.

There could be some logical reasons for the UK leaving the EU, but the important problem or the most important question for the UK is what the country will do next after separating from the EU after long years of cooperation. It is approximately two years since the UK voted to leave the EU and during this time negative developments have been witnessed in the economic growth rates of England and the euro area. The process for England is full of negativity and risks.

At this point the EU member countries who have the willingness to hold a referendum similar to Brexit, will wait to assess how the developments proceed in the United Kingdom. In other words, they will wait and see what the positive and negative impacts of Brexit for the United Kingdom will be. It is therefore likely that, in the short-term or in the middle-term there will be no referenda similar to Brexit in any member country of the EU.

On the other hand, in the long run there is a risk of collapse of the UK. For example, in the long run, Scotland and/or Northern Ireland may attempt to achieve their own independence. In fact, Scotland has already made an attempt to gain independence, where elections were held in 32 different regions of the country and the majority voted to remain in the United Kingdom, rejecting the possibility of becoming an independent nation. 
England must pay more attention to Scotland and Northern Ireland and at the same time should be more interested in their problems and complaints. After choosing to leave the EU the United Kingdom has already become uncertain and if the UK is faced with the further threat of break up, then this could present an even more precarious situation. The UK can therefore mitigate the damaging effects of leaving the EU by calming the shock generated by the situation, thus removing the uncertainty as soon as possible.

The UK is not only an important nation for the EU, but it is also significantly important for global economics and politics. The United Kingdom maintains an American dependent foreign policy which increases its importance in global politics. When the economic extent and the share of the United Kingdom in the global economy is taken into consideration then it is seen that, the steps that the UK government takes will have an impact on the world. If the wide ranging and efficient role played by the United Kingdom and the United States in the Middle-East is considered it will be easier to understand why the steps taken by the UK are important for the whole world.

Now the EU is considering the most effective way of responding to Brexit. Recently there are discussions in Paris and Berlin over a new EU treaty which will be centralized on a more integrated euro zone. However, there is no harmonization between France and Germany solving the problems of the euro. Even though France and Germany can achieve harmonization, the parliaments in those two countries will not be willing to transfer any power to the euro zone or the institutions of the EU. If a new EU treaty is established then there must be referenda in Denmark, Ireland, the Netherlands, and perhaps in France, which could easily result in those countries choosing to leave the EU. Hence there is no possibility of a major new treaty being introduced. The European leaders have to work on reforming the EU through the passages of laws, and there is also a need for budget revision and intergovernmental agreements. The EU leaders may accept new laws which will offer solutions to the difficulties in the euro zone or the refugee situation, and perhaps the new mentioned laws could increase the power of the EU institutions. The governments in the European Union must keep the European Commission and the European Parliament under strict observation.

Brexit may also have impacts on the candidate countries to the EU membership and can create some risks for the collapse of the EU. Turkey is currently a candidate country for membership to the EU. The negotiations between Turkey and the EU are still ongoing. Furthermore, it is evident that negotiations between the two sides are not progressing positively. Because of the unstable political relations between Turkey and the EU, this has led to a slowdown in the negations. The UK's decision to discontinue its EU membership has impacts on both the EU members as well as prospective EU membership candidates. After Brexit decision, where the majority of the people in the UK voted to leave the EU, this may encourage some other EU members to hold similar referenda. Furthermore, the desire of countries that are 
candidates for EU full membership may consequently diminish. Certainly, it is important to mention at this point that the impacts of Brexit will generally be seen in the long-run for the members and the candidates of the EU.

\section{References:}

Baimbridge, M., Burkitt, B. 2000. The Impact of the Euro Debating Britian's Future. Macmillan Press.

Cecchetti, S. 2008. Money, Banking, and Financial Markets, 2nd edition. McGraw-Hill International Edition.

Daniels, J.P., Van Hoose, D. 2011. Global Economic issues and policies, $2^{\text {nd }}$ edition. Routledge.

David, D. 1999. The European Economy, 2nd edition. Addison Wesley Longman Limited.

Eicher, T., Mutti, J., Turnovsky, M. 2009. International Economics, 7th edition. Routledge Taylor \& Francis Group.

El-Agraa, A. 2007. The European Union Economics and Politics, $8^{\text {th }}$ edition. Cambridge University Press.

El-Agraa, A. 2004. The European Union Economics and Politics, $7^{\text {th }}$ edition. Prentice Hall.

European Economy, European Comission Dicrectorate-General for Economic and Financial Affairs: The EU Economy. 2000. Review.

Feenstra, R. and Taylor, A. 2012. International Economics, $3^{\text {rd }}$ edition. Worth Publishers.

Hancock, D. and Carman, C. 2007. Politics in Europe, 4th edition.

Karluk, R. 1996. International Economy, Expanded, Revised 4th Edition. Beta Publishing House.

Kidwell, D., Blackwell, D. 2002. Financial Institutions, Markets and Money. John Wiley \& Sons.

McCormick, J. 2005. Understanding the European Union, 3rd edition. Palgrave Macmillan.

Nello, S. 2005. The European Union, economics, policies and history. The McGraw-Hill Companies.

Özdeşer, H. 2015. Management and Economics. Celal Bayar University.

Pelkmans, J. 2001. European Integration Methods and Economic Analysis, $2^{\text {nd }}$ edition. Prentice Hall.

Thalassinos, I.E. and Pociovalisteanu, M.D. 2009. The Structural Funds and the Economic and Social Cohesion Process. Annals-Economy Series 1, 313-330.

Thalassinos, I.E., Stamatopoulos, D.T. and Thalassinos, E.P. 2015. The European Sovereign Debt Crisis and the Role of Credit Swaps. Chapter book in The WSPC Handbook of Futures Markets (eds) W. T. Ziemba and A.G. Malliaris, in memory of Late Milton Miller (Nobel 1990) World Scientific Handbook in Financial Economic Series Vol. 5, Chapter 20, pp. 605-639, ISBN: 978-981-4566-91-9, (doi: 10.1142/9789814566926_0020).

Salvatore, D. 2007. International Economics, $9^{\text {th }}$ edition.

Seyidoğlu, H. 2007. International Economics, Theory Policy and Practice, 16th Edition.

Yarbrough, B. and Yarbrough, R. 2006. The World Economy Trade and Finance. $7^{\text {th }}$ edition, Thomson South-Western.

Zestos, G. 2006. European Monetary Integration, The Euro. Thomson South Western. 